\title{
Taxonomy and distribution of the green algal genus Halimeda (Bryopsidales, Chlorophyta) in Brazil ${ }^{1}$
}

\author{
MARIA ELIZABETH BANDEIRA-PEDROSA ${ }^{1}$, SONIA M.B. PEREIRA ${ }^{1}$ \\ and EURICO C. OLIVEIRA ${ }^{2,3}$
}

(received: July 11, 2003; accepted: February 19, 2004)

\begin{abstract}
Taxonomy and distribution of the green algal genus Halimeda (Bryopsidales, Chlorophyta) in Brazil). Halimeda is a genus of calcified coenocytic green algae with a well known ecological importance in some tropical areas. Bleached calcified segments of Halimeda may accumulate in large deposits of economic potential as is the case in the northeastern coast of Brazil. In a survey of the genus in Brazil based on recent collections and examination of abundant material deposited on Brazilian herbaria we identified seven species: Halimeda cuneata Hering, H. discoidea Decaisne, H. gracilis Harvey ex J. Agardh, H. incrassata (Ellis) Lamouroux, H. opuntia (Linnaeus) Lamouroux, H. simulans Howe and H. tuna (Ellis \& Solander) Lamouroux. These species are described in detail, with emphasis on diagnostic characters. Our study has shown that the shape and size of the utricula in surface view, under scanning electron microscopy, can be utilized to discriminate some species. Fertile specimens of Halimeda cuneata and H. discoidea are reported for the first time in the region. Data on vertical and geographical distribution are presented for each species and the southern limit of the genus in the western Atlantic was extended.
\end{abstract}

Key words - Brazil, Bryopsidales, Halimeda, Halimeda cuneata

RESUMO - (Taxonomia e distribuição do gênero de algas verdes Halimeda (Bryopsidales, Chlorophyta) no Brasil). Halimeda é um gênero de algas verdes de talo cenocítico e calcificado que desempenha importante papel ecológico em regiões tropicais. Segmentos calcificados e branqueados de Halimeda podem-se acumular em grandes depósitos com potencial econômico, como ocorre na costa nordeste do Brasil. O levantamento do gênero no Brasil, baseado em coletas recentes e em abundante material depositado em herbários brasileiros, mostrou a presença de sete espécies: Halimeda cuneata Hering, H. discoidea Decaisne, H. gracilis Harvey ex J. Agardh, H. incrassata (Ellis) Lamouroux, H. opuntia (Linnaeus) Lamouroux, H. simulans Howe e H. tuna (Ellis \& Solander) Lamouroux, as quais são descritas em detalhe, com ênfase nos caracteres diagnósticos. Nossos estudos mostraram que a forma e tamanho dos utrículos em vista frontal, vistos em microscopia eletrônica de varredura, permite a distinção entre algumas espécies. Exemplares férteis de Halimeda cuneata e H. discoidea são descritos pela primeira vez para a costa brasileira. Para cada espécie é indicada a distribuição vertical e geográfica na costa brasileira, extendendo-se o limite sul de distribuição do gênero no Attântico ocidental.

Palavras-chave - Brasil, Bryopsidales, Halimeda, Halimeda cuneata

\section{Introduction}

The genus Halimeda Lamouroux is characterized by a coenocytic thallus constructed of a system of interwoven bifurcated siphonous filaments that expand into utricles at the thallus surface. Macroscopically, the thallus is characterized by a series of green articulated coin shaped segments made rigid by the impregnation of calcium carbonate as aragonite (Gilmartin 1960, Borowitska \& Larkum 1977).

1. Universidade Federal de Pernambuco, Departamento de Biologia, Rua Dom Manoel de Medeiros, s/n, 52171-900 Recife, PE, Brazil.

2. Universidade de São Paulo, Instituto de Biociências, Caixa Postal 11461, 05422-970 São Paulo, SP, Brazil.

3. Corresponding author: euricodo@usp.br
Species recognition has been based mainly on the gross morphology of the segments, branching pattern, position and shape of holdfasts. Anatomy provides additional distinctive characters such as the size and shape of the utricles and structure of the node joining two successive segments (Barton 1901, Taylor 1950, Hillis 1959, Hillis-Colinvaux 1980). Hillis-Colinvaux (1980) divided the genus into five sections based on the patterns of nodal structure: Rhipsalis, Opuntia, Halimeda, Micronesicae and Crypticae. Hillis et al. (1998) based on a partial sequence of the 18S rDNA found a good correlation between several morphological characters and the molecular data, but recognized only three lineages: Rhipsalis, Opuntia and Halimeda. More recently Kooistra et al. (2002) extended considerably the sequencing study of Hillis et al. (1998) including SSU and ITS 1 and 2 regions; although they recognized the relevance of nodullary siphons structure and 
arrangement, they rejected the sectional treatment of Hillis-Colinvaux (1980).

The genus is broadly distributed in the tropics, being represented by 33 species (Hillis et al. 1998). The following species have been reported from Brazil: Halimeda discoidea Decaisne, H. gracilis Harvey ex J. Agardh, H. incrassata (Ellis) Lamouroux, H. opuntia (Linnaeus) Lamouroux, $H$. simulans Howe and H. tuna (Ellis \& Solander) Lamouroux (Horta \& Oliveira 2002). However their circumscription is not always clear and varies with the author.

This study is a critical revision of the species that occur in Brazil based on the analysis of abundant material. Information on scanning electron microscopy (SEM) of thallus surface is presented for the first time and a map showing the geographical distribution of the species along the Brazilian coast is provided, extending the southern limit of the genus in the American Atlantic.

\section{Material and methods}

Recent material was collected from the intertidal and infralittoral zones during low tide by skin diving from 1997 to 2000 on several places of the northeastern coast of Brazil, and dredged during an extensive national program to survey the Brazilian platform (REVIZEE). We also studied material collections deposited in Brazilian herbaria (ALCB, IPA, JPB, PEUFR, RFA, SP, SPF and UFP) and the lectotype of Halimeda cuneata at BM. For the sake of brevity only a few selected specimens of the long list of material studied are included here.

For light microscopy, specimens were preserved in $4 \%$ Formalin and decalcified in $20 \% \mathrm{HCl}$. Dried herbarium specimens were immersed in 50\% glycerol for 24 hours and then processed as described for liquid preserved specimens. Longitudinal and cross sections were made with steel blades. Nodal regions were dissected with needles, and the preparations were mounted in a $50 \%$ glycerol solution. Structure sizes are reported as the mean of ten measurements, with the extreme values indicated between brackets.

For scanning electron microscopy (SEM), small portions of mature segments were pre-fixed in the field in $2.5 \%$ glutaraldehyde in $0.1 \mathrm{M}$ sodium phosphate buffer, $\mathrm{pH} 7.0$, and kept on ice. The material was then rinsed in the same buffer, post-fixed in $2 \%$ osmium tetroxide, dehydrated in an ethanol series (30\% to 100\%), dried in hexamethildezilasane (HMDS), sputter-coated with gold and observed in a MEV Phillips XL30.

\section{Results}

Although aware that the sections established by Hillis-Colinvaux (1980) are not supported by molecular data according to Kooistra et al. (2002) we decided to keep this traditional arrangement for the time being.

\section{Section Rhipsalis J. Agardh ex De Toni}

Characterized by having nodal medullary siphons fused all together for a short extension and with a sequence of pits. This section is represented in Brazil by Halimeda incrassata and $H$. simulans, both included in "lineage 1" of Kooistra et al. (2002).

Halimeda incrassata (Ellis) Lamouroux, Nouv. Bull. Sci. Soc. Philom. 3:186. 1812. = Corallina incrassata Ellis, Philosophical Transactions 57: pl.17, figs. 20-27. 1767.

Type locality: Jamaica

Figures 1, 20, 24, 25.

Thallus erect, single or gregarious, strongly calcified at the base and less so at the upper segments; color light-green, becoming whitish on drying; up to $27 \mathrm{~cm}$ long; branching mainly di- to tetrachotomous; holdfast bulbous; the first two basal segments cylindrical and the third one usually flabellate, about $10 \mathrm{~mm}$ wide and $8 \mathrm{~mm}$ long; upper segments subcylindrical, cuneate or reniform, $9 \mathrm{~mm}$ wide by $6 \mathrm{~mm}$ long (figure 1). Cortex with up to five layers of utricles; external utricles hexagonal in outline, $72(52-92) \mu \mathrm{m}$ in diameter in surface view (figure 20) and 81 (59-103) $\mu \mathrm{m}$ long in cross-section holding together even after decalcification (figure 24); every secondary utricle 53 (44-74) $\mu \mathrm{m}$ long, gives rise to two primary ones; nodal medullary siphons interwoven and fused all together for not more than $100 \mu \mathrm{m}$, with conspicuous pores (figure 25).

Selected material: BRASIL: CEARÁ: Guajiru, Trairi, 21-XII-1991, N.P. Dantas (PEUFR17866). Rio GRANDE Do Norte: $05^{\circ} 04^{\prime}$ 'S, 35²5'W, 16 m, 26-II-1980, G.C.

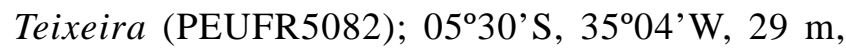
2-II-1997, REVIZEE (PEUFR35121). Pernambuco: Tamandaré, 10-III-1999, M.E. Bandeira-Pedrosa \& M.D. Santos (PEUFR35117); 07047'S, 34²9' W, 52 m, 17-X-1995, REVIZEE, (PEUFR35124). Paraíba: 07¹8'00"S, 34³3'00”'W, 30 m, 14-II-1980, F.R. Lima (PEUFR6464); Monumento, Cabedelo, 28-VII-68, S.M.B. Pereira (SPF27553). Alagoas: 09²0'S, 3505'W, 45 m, 9-IX-1965, s.col. (SPF25967).

This species was found from Ceará through the state of Bahia (figure 42), collected from the intertidal up to a depth of $53 \mathrm{~m}$. Populations from Pernambuco were found partially buried in sand among beds of the angiosperm Halodule wrightii Ascherson. Specimens 
from the subtidal are more robust and with the typical reniform segments, whereas the intertidal ones have subcylindrical segments.

Halimeda simulans Howe, Bull. Torrey Bot. Club 34:503. 1907.

Type locality: Puerto Rico

Figures 2, 22, 26, 27.

Thallus erect, single or gregarious, lightly calcified at the base and less so at the upper segments; color dark-green when alive, becoming light-green on drying; up to $14 \mathrm{~cm}$ long; branching mainly di-trichotomous; holdfast bulbous; the first two basal segments short, subcylindrical, subcuneate; upper segments discoid to reniform, with imbricated aspect and up to $12 \mathrm{~mm}$ wide and $9 \mathrm{~mm}$ long (figure 2). Cortex with up to four layers of utricles; external utricles keep together even after decalcification (figure 26), hexagonal in outline, and similar to $H$. incrassata, in surface view, but smaller with $38(18-48) \mu \mathrm{m}$ in diameter (figure 22) and 34 (22-48) $\mu \mathrm{m}$ long in cross section. Every secondary utricle supports 2-4 primary ones; secondary utricles 62 (55-92) $\mu \mathrm{m}$ long. Medullary siphons interwoven, with short nodal fusions, forming a single group with inconspicuous pores (figure 27).

Selected material: BRASIL: PERNAMBUCO: Fernando de Noronha Archipelago: $03^{\circ} 27^{\prime} \mathrm{S}, 35^{\circ} 02^{\prime} \mathrm{W}, 58 \mathrm{~m}$, 4-VI-1998, REVIZEE (PEUFR35027); 0446'S, 35²4'W, 39 m,16-X-1967, Almirante Saldanha (SPF25972); Itamaracá, 8-VIII-1968, P. Montouchet (SPF29381); Recife, Boa Viagem 28-VIII-1963, D.B.

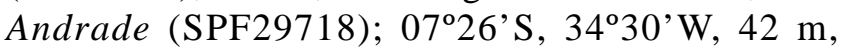
12-V-1998, REVIZEE (PEUFR35026). BAHIA: Barra do Gil, Itaparica, 9-VIII-1998 M.E. Bandeira et al. (PEUFR35126); Itaparica, Mar Grande, 7-VII-2000, M.C. Accioly (PEUFR35025); 13³8'S, 38²5' W, 50 m, 19-X-1997, REVIZEE (PEUFR36497).

This species was found in the state of Pernambuco, Fernando de Noronha Archipelago and the state of Bahia (figure 42), being collected from the intertidal up to a depth of $63 \mathrm{~m}$. In Bahia this species occurs in dense intertidal populations among Penicillus capitatus Lamouroux, Caulerpa spp., Udotea spp. and Halimeda opuntia. Intertidal specimens are more vigorous and calcified than the subtidal ones. Williams \& Blomquist (1947) were the first to report the occurrence of $H$. simulans in Brazil (coast of Pernambuco and Fernando de Noronha Archipelago), which was considered as uncertain by Oliveira Filho (1977), in the absence of material for confirmation. Later on, Ugadim
\& Pereira (1978) found it among material dredged from Pernambuco, which is now confirmed.

Section Opuntia J. Agardh ex De Toni

This section is characterized by having nodal medullary siphons fused in pairs for a short distance. It is locally represented by only one species, Halimeda opuntia, which is included in "lineage 5" of Kooistra et al. (2002).

Halimeda opuntia (L.) Lamouroux, Nouv. Bull. Sci. Soc. Philom. 3:186. 1812. ECorallina opuntia L., Syst. Nat. p.805. 1758.

Type locality: Jamaica

Figures 3-5, 21, 28-30.

Thallus erect, forming compact or loosely prostrate tufts, strongly calcified; color light-green to whitish up to $34 \mathrm{~cm}$ long; branching polystichous, attached to the substrate by multiple holdfasts; segments variable in shape, usually trilobate, flattened to cylindrical, sometimes twisted, auriculated to crenulated ca. $18 \mathrm{~mm}$ in diameter and $9 \mathrm{~mm}$ long; remaining segments discoid to cuneate, with up to $12 \mathrm{~mm}$ wide and $9 \mathrm{~mm}$ long (figures 3-5). Cortex with 3-5 layers of utricles dichotomously branched (figure 28); external utricles rounded to polygonal, lightly coalescent after decalcification, 29 (15-44) $\mu \mathrm{m}$ in diameter, in surface view (figure 21), and 30 (26-41) $\mu \mathrm{m}$ long in cross section. Every secondary utricle supports 2 primary ones. Nodal medullary siphons interwoven, fused in pairs, seldom in groups of 3-4, with short nodal fusions (figures 29, 30).

Selected material: BRASIL: CEARÁ: Guajiru, Trairi, 21-XII-1991, N.P. Dantas (PEUFR17867). Rio GRANDE DO NORTE: 0509'05"S, 3508'05'W, 28 m, 5-II-1980, G.C. Teixeira (PEUFR5016); 05³0' $\mathrm{S}, 35^{\circ} 04^{\prime} \mathrm{W}, 29 \mathrm{~m}$, 2-II-1997, REVIZEE (PEUFR35078); 0447'S, 35²0'W, $44 \mathrm{~m}$, 13-X-1995, REVIZEE (PEUFR35079). Pernambuco: Jaboatão dos Guararapes, Candeias, 21-I-1962, I. Pontual (PEUFR1215); Tamandaré, Campas, 3-XII-1990, J.A.P. Angeiras \& A.S. Lopes (PEUFR20564); Itamaracá, Jaguaribe, 18-IX-1997, M.E. Bandeira-Pedrosa \& M.F.B. Oliveira (PEUFR35042); Ipojuca, Serrambí, 16-X-1997, M.E. Bandeira-Pedrosa \& A.L.M. Cocentino (PEUFR35045); Porto de Galinhas, 15-XII-1997, M.E. Bandeira-Pedrosa \& A.L.M. Cocentino (PEUFR35051); Tamandaré, 10-III-1999, M.E. Bandeira-Pedrosa (PEUFR35061); Paulista, Nossa Senhora do Ó, 24-XI-1957, A. Lima (IPA11370); Paulista, Janga, 11-V-1972, M.G. Pessoa (UFP3975). 


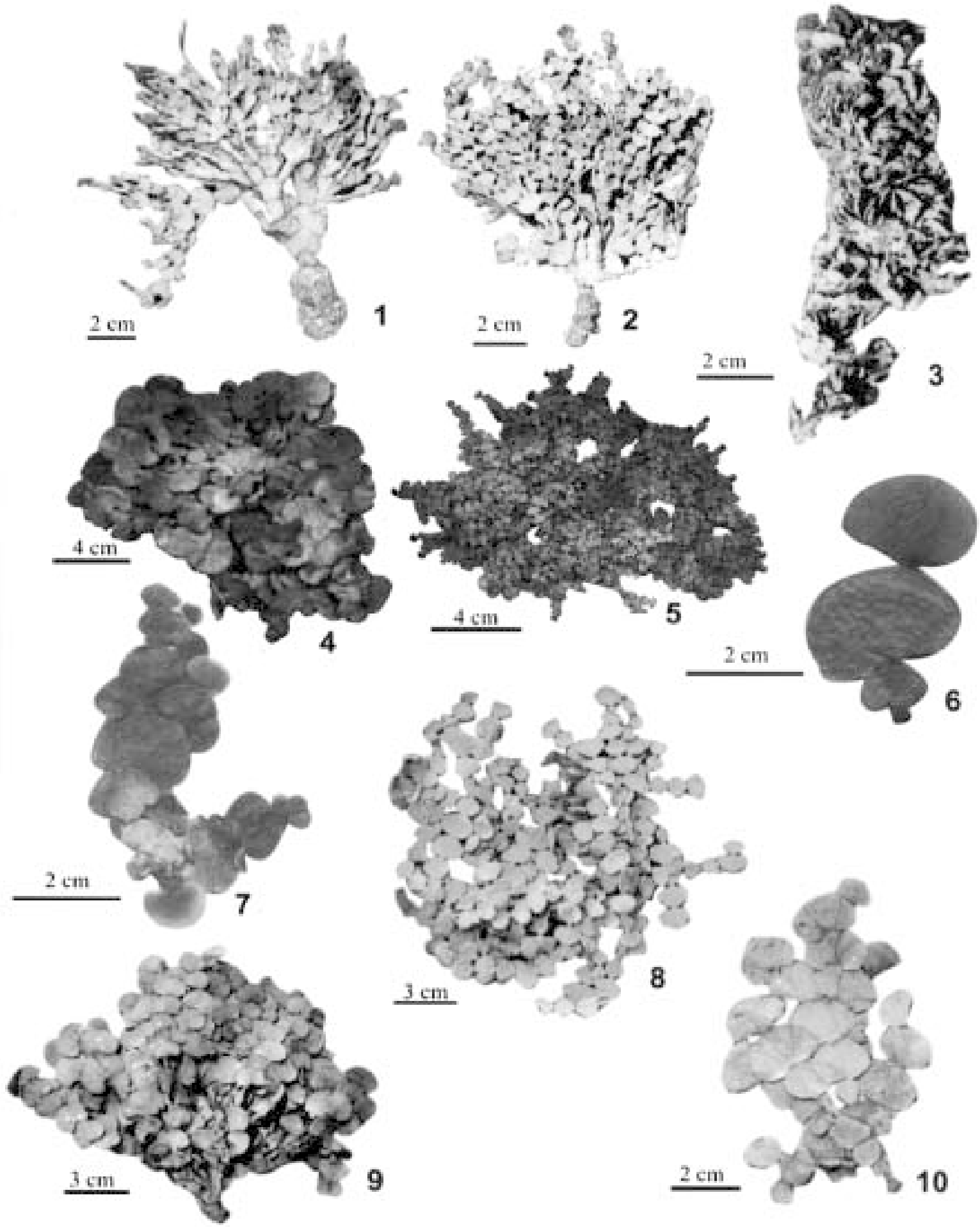

Figures 1-10. General morphology of species of Halimeda. 1. Halimeda incrassata, gross morphology showing terete and subcuneate segments. 2. Halimeda simulans, gross morphology showing reniform and cuneate segments. 3-5. Variability of Halimeda opuntia gross morphology; specimens from shallow water. 3. Compact and more elongated specimen. 4. Specimen with compact erect tufts. 5. Specimen with loose, prostrate tufts. 6-7. Halimeda discoidea. 6. Specimen from deep water, with less dense branching, and larger discoid segments. 7. Specimen from shallow water, showing denser branching and small reniform segments. 8. Halimeda gracilis, a deep water specimen, with broad reniform segments. 9-10. Halimeda tuna. 9. Shallow water specimen, with denser branching, and smaller well calcified segments. 10. Deep water specimen, note loose branching, larger and less calcified segments. 
Paraíba: Cabo Branco, 27-V-1998, M.E. BandeiraPedrosa \& A.I. Kanagawa (PEUFR35063). Alagoas: Francês, 26-IV-1998, M.E. Bandeira-Pedrosa \& E.A.C. Guedes (PEUFR35064); Barra de São Miguel, 26-IV-1998, M.E. Bandeira-Pedrosa \& E.A.C. Guedes (PEUFR 35065); Paripueira, 28-IV-1998, M.E. BandeiraPedrosa \& E.A.C. Guedes (PEUFR35127); Pajuçara, 29-I-1965, E.C. Oliveira (SP96476). B AHIA: Itaparica, M.E. Bandeira-Pedrosa et al. (PEUFR35073); Salvador, Forte, 6-VIII-1998, M. Accioly (PEUFR35077); Itaparica, Coroa, 28-XI-1981, Y. Ugadim (SPF25975); Salvador, Pituba, I-1977, E.C. Oliveira (SPF51423).

Adittional material studied (H.M.S. Challenger Exp.): Admiralty Isles, H.N. Moseley 1876 (BM); BAHIA: Barra Grande-Brazil, H.N. Moseley 1876 (BM); Pernambuco: Fernando de Noronha Archipelago, H.N. Moseley 1876 (BM).

This is the most common and widespread species of Halimeda worldwide, being considered pantropical. In Brazil the it is more common in the intertidal, but was also dredged at $44 \mathrm{~m}$, from Ceará State to Rio de Janeiro (figure 42). Its morphology is variable: on reef flats tufts are more compact and imbricated with twisted segments, whereas on reef vertical walls tufts are more loose, branching tend to become distichous and segments are auriculate assuming the cordate form described by Barton (1901).

This species may have a key ecological role due to its high biomass and percentage of substrate cover. In some places it forms dense beds inhabited by a large diversity of invertebrates; in others their dead segments accumulate in large amounts and are sporadically utilized as a source of carbonates.

\section{Section Halimeda}

This section is characterized by short nodal medullary siphons extensively fused in groups of 2-3. The following species are present in Brazil: Halimeda cuneata, $H$. discoidea, $H$. tuna and $H$. gracilis. The first three are included in the "lineage 3" and the last one in "lineage 4" of Kooistra et al. (2002).

Halimeda cuneata Hering in Krauss, Flora p.209. 1846. Type: SOUTH AFRICA: NATAL: Dulham, Krauss s.n., 1839 (Lectotype BM!, designated by Hillis-Colinvaux 1980)

Figures 11-17, 31-34.

Thallus erect, single, lightly calcified; color darkgreen, becoming white or yellowhish on drying; up to
$25 \mathrm{~cm}$ long; branching sparse to dense, usually dichotomous but also trichotomous to irregular in places and with up to 8 segments on a series without furcation (figures 11-14); holdfast basal and small; the first two basal segments are cylindrical or subcylindrical; upper segments are flat, cuneate to trapezoid, sometimes discoid with a smooth and shiny surface measuring up to $25 \mathrm{~mm}$ wide by $20 \mathrm{~mm}$ long; most of the segments are joined by a sort of short stipe, $1 \mathrm{~mm}$ long and $6 \mathrm{~mm}$ in diameter (figure 15), composed by densely interwoven, torulose and thick-walled filaments (figure 16). Cortex with three layers of utricles, seldom four; external utricles goblet shaped, keeping firmily together after decalcification; fused utricles were seen occasionally; external utricles are polygonal in surface view (figure 17) with 52 (22-66) $\mu \mathrm{m}$ in diameter; in cross section they measure 104 (74-144) $\mu \mathrm{m}$ long; secondary utricles suport 2-4 primary ones (figure 31); nodal medullary siphons interwoven and fused in groups of 2-3 for a variable extent (figures 32,33); above the node the medullary filaments have thick walls and are pigmented, and may have a small tuft of short utricles above the point of filament fusions (figure 32). Gametophores are produced from the primary utricles and have 4-7 pedunculated gametangia, $370 \mu \mathrm{m}$ long and $140 \mu \mathrm{m}$ in diameter (figure 34).

Selected material: BRASIL: RIO GRANDE DO NORTE: 05 09'05"S, 35¹1'00”'W, 20 m, 5-II-1980, G.C. Teixeira (PEUFR5017). PARAÍBA: 06³3'S, 3447'05"W, 26 m, 4-VI-1981, F.R. de Lima (PEUFR6510). B Aнia: Itaparica, Mar Grande, 6-X-1964, A.B. Joly \& Y. Ugadim (SPF630); Salvador, Amaralina, 4-X-1964, A.B. Joly \& Y. Ugadim (SPF1829); Ilhéus Grande, 15-I-1965, E.C. Oliveira (SPF54706); Itapoã, 20-IV-1987, G. Mitchell (RFA4991); Forte, 6-VIII-1998, M.E. BandeiraPedrosa \& M.C. Accioly (PEUFR35028); Itaparica, Mar Grande, 9-VIII-1998, M.E. Bandeira-Pedrosa \& M.C. Accioly (PEUFR35032); Salvador, Itapoã, 29-VI-2000, M.E. Bandeira-Pedrosa \& M.C. Accioly (PEUFR35035). Espírito S Anto: Ponta da Fruta, 19-VIII-1978, E.C. Oliveira (SPF 26021); Piuma, Acaiaca, 18-VIII-1978, E.J. Paula (SPF26022); Ilha do Francês, 30-V-1986, prof. 15 m, E.C. Oliveira (SPF28801); Itaipava, 17-III-1988, E.C. Oliveira (SPF52193); Manguinhos, 20-I-1973, E.C. Oliveira \& L. Behar (SPF53490); Ponta da Fruta, 4-VII-1985, fértil, E.J .Paula (SPF53739); Santa Cruz, 23-VI-1986, G. Mitchell (RFA4605); Vitória, Camburí, 22-VI-1994), C. Nassar (RFA9256).

Additional material studied: SOUTH AFRICA: 

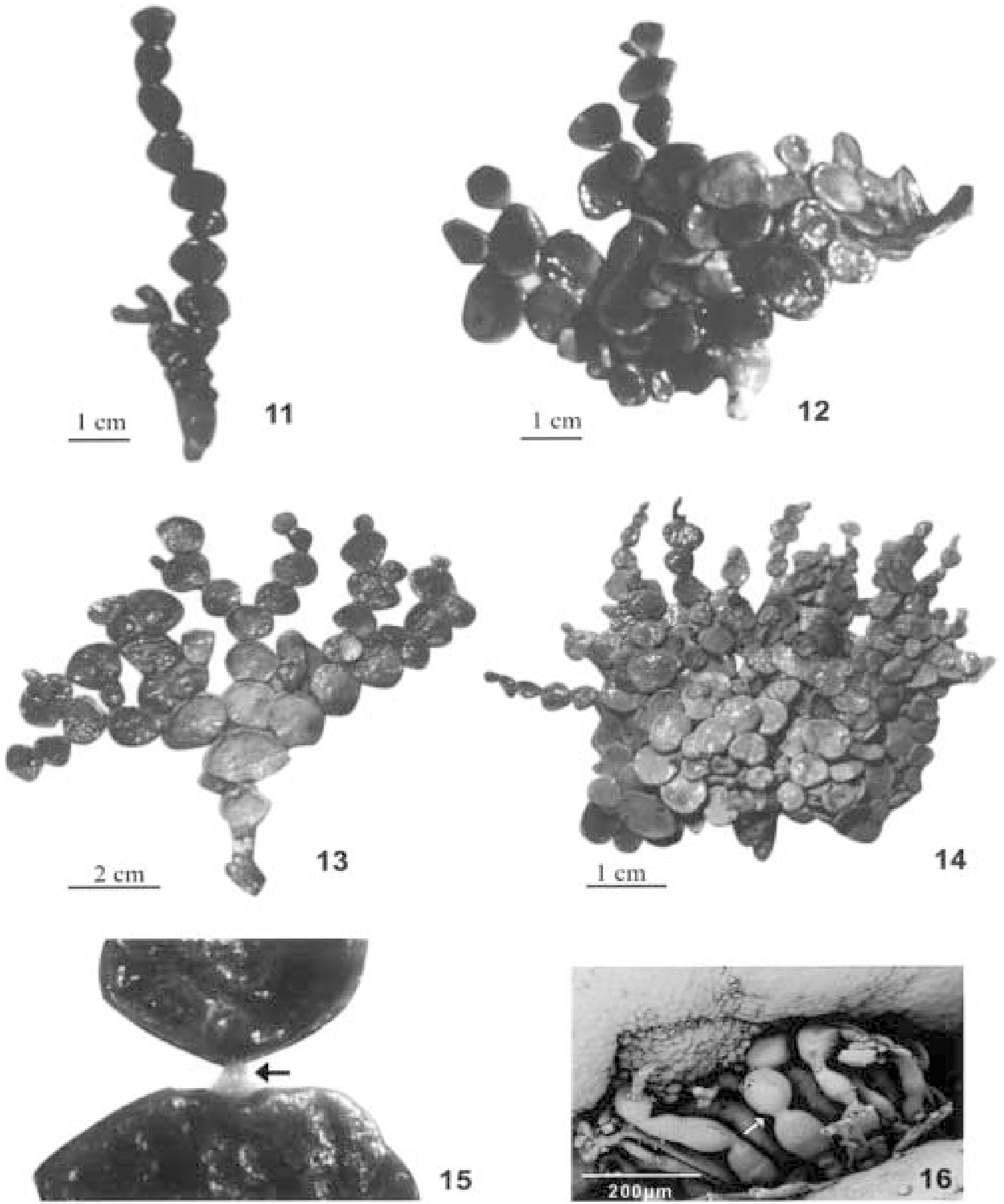

$\overline{1 \mathrm{~mm}}$

Figures 11-16. Halimeda cuneata. 11-14. Variability in branching pattern. 15. Detail of nodal region (arrow). 16. Cushion-like nodal region with torulose filaments, SEM. 

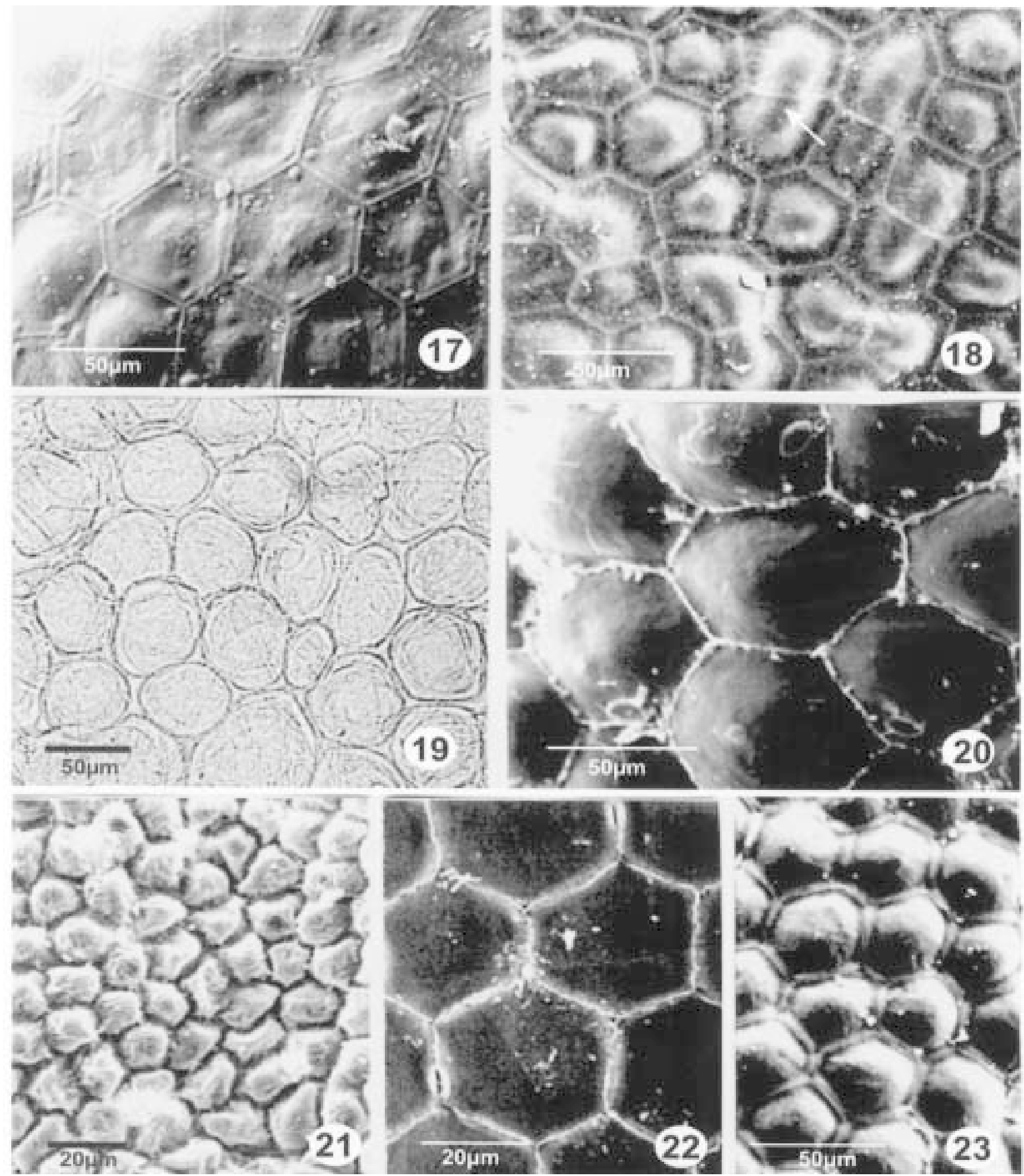

Figures 17-23. Surface SEM views (except figure 19, LM view) of segments of different species of Halimeda. 17. Surface view of a segment of Halimeda cuneata with hexagonal outline. 18. Surface view of a segment of Halimeda discoidea with hexagonal to pentagonal outline. Note fusion of utricles (arrow). 19. Light micrograph. Surface view of a segment of Halimeda gracilis with rounded outline. 20. Surface view of a segment of Halimeda incrassata. Note size hexagonal outline of the utricles. 21. Surface view of a segment of Halimeda opuntia. Note size and irregular outline of the utricles. 22. Surface view of a segment of Halimeda simulans. Note delicate small utricles. 23. Surface view of a segment of Halimeda tuna. Note polygonal outline and thick convex cell wall. 

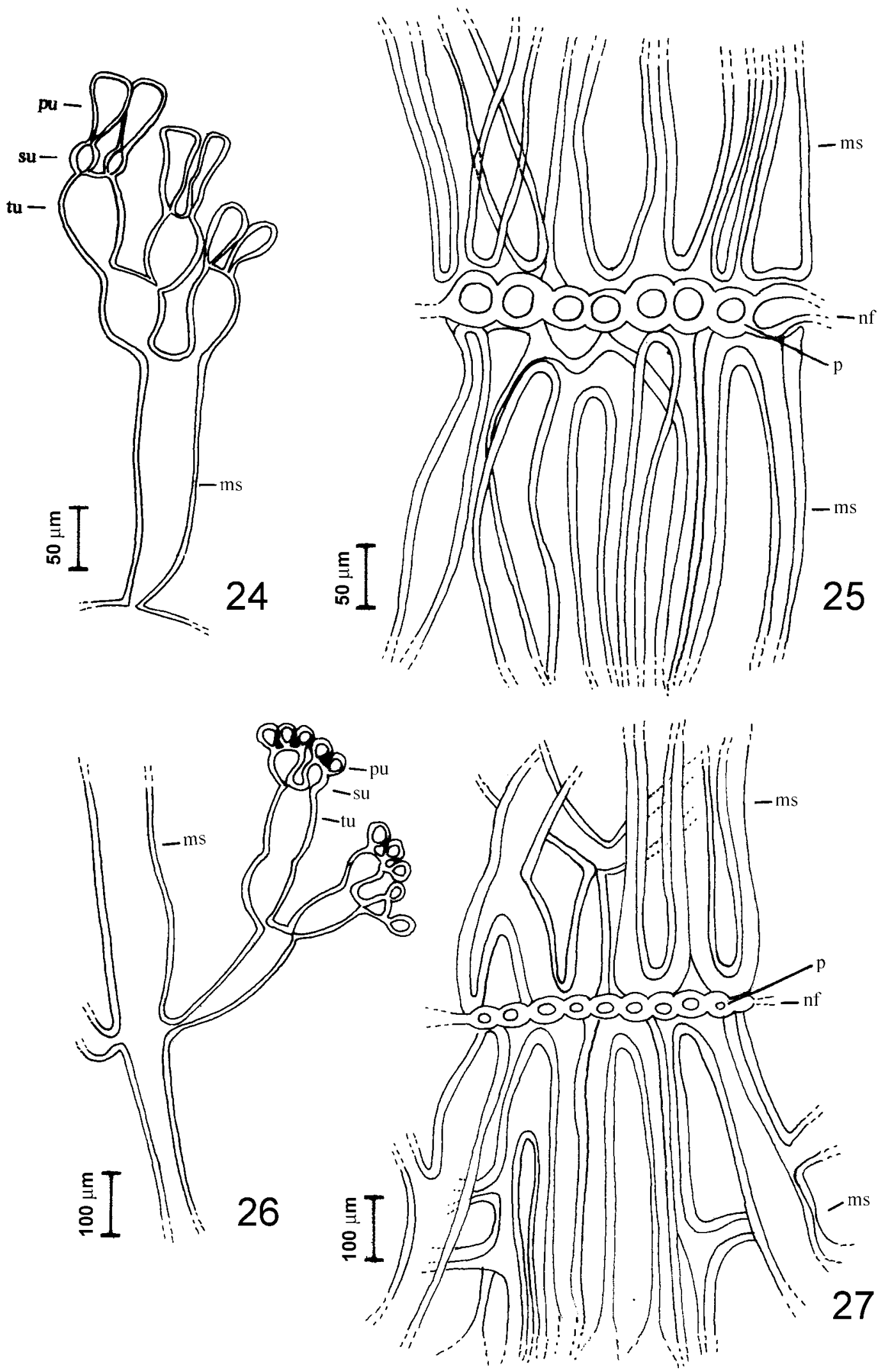

Figures 24-25. Halimeda incrassata. 24. Detail of primary, secondary and tertiary utricles and medulary siphons (ds). 25. Detail of nodal fusion and pores (1s). Figures 26-27. Halimeda simulans. 26. Detail of primary, secondary and tertiary utricles and medulary siphons (ds). 27. Detail of nodal fusion and pores (ls). 

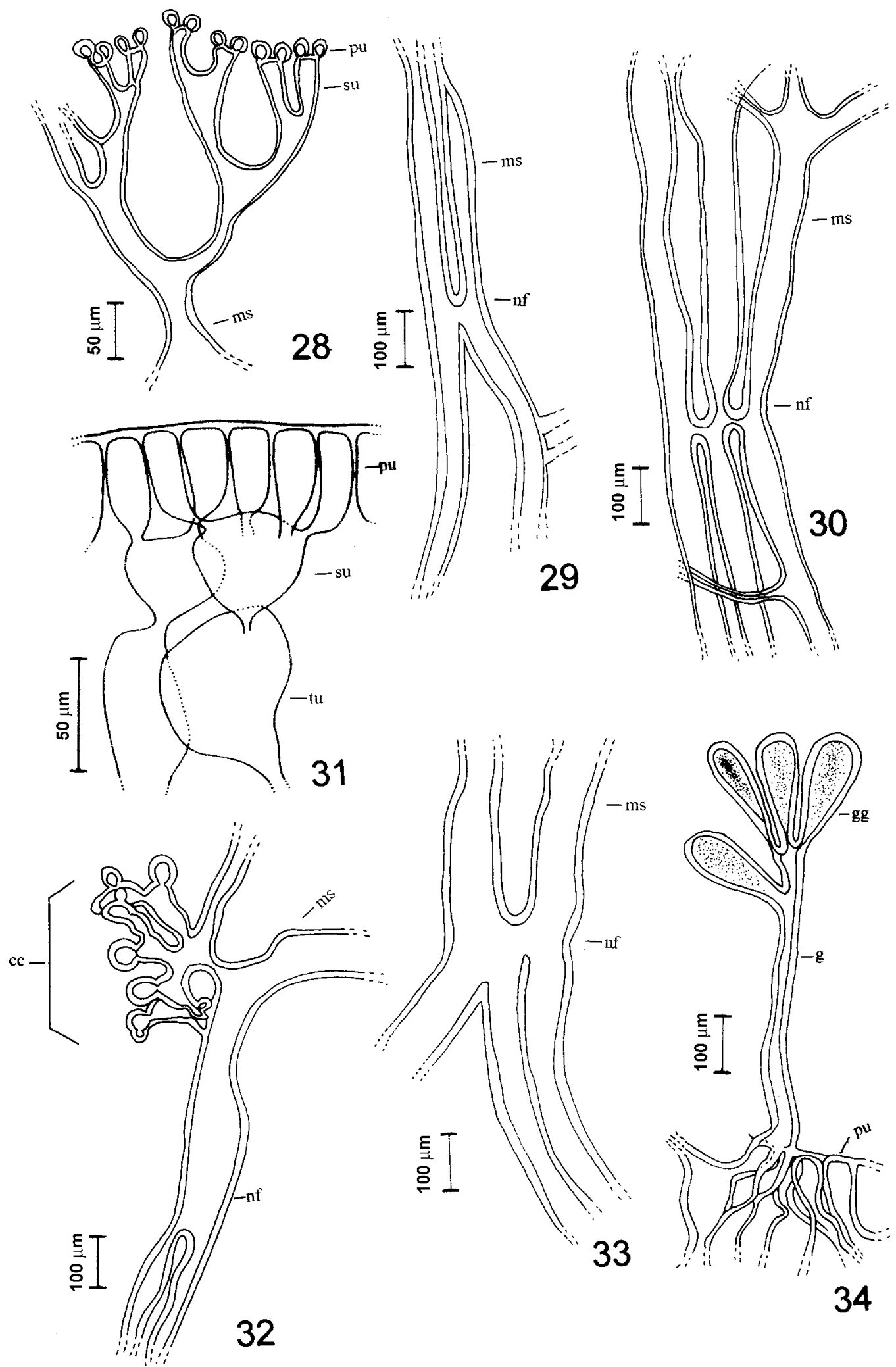

Figures 28-30. Halimeda opuntia. 28. Detail of primary and secondary utricles (ds). 29. Short nodal fusion in paired groups (1s). 30. Short nodal fusion in a group of three medullary siphons (1s). Figures 31-34. Halimeda cuneata. 31 . Detail of primary, secondary and tertiary utricles and medulary siphons (ds). 32. Thickening of cell wall of nodal siphons above the point of fusion and compact cortex (1s). 33. Short nodal fusion of three medullary siphons (1s). 34. Branched gametophore produced from the layer of primary utricles with gametangia (ds). 


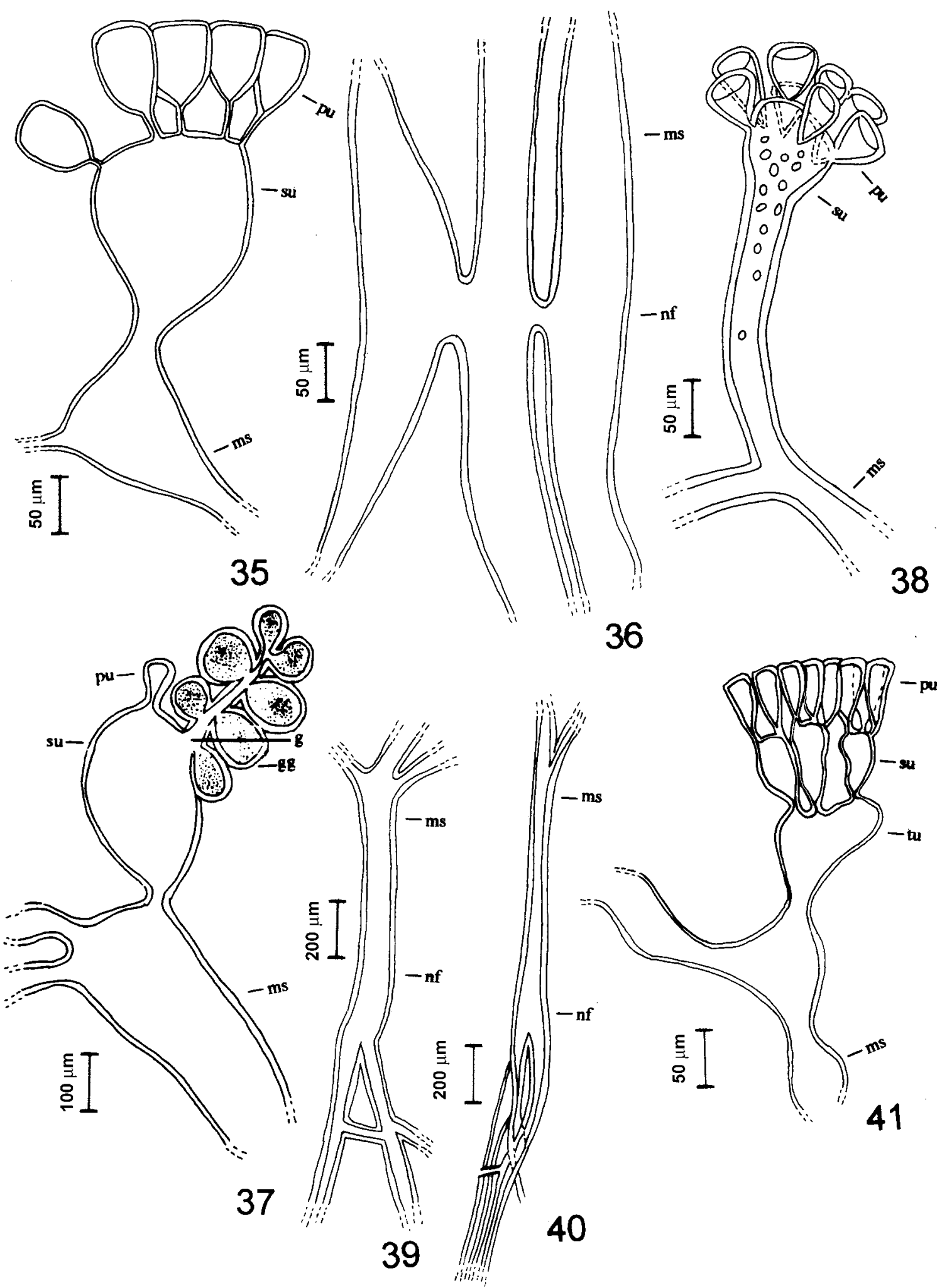

Figures 35-37. Halimeda discoidea. 35. Detail of primary and secondary utricles (ds). 36. Short nodal fusion of three medullary siphons. 37. Branched gametophore produced from secondary utricles (ds). Figures 38-40. Halimeda gracilis. 38. Detail of primary and secondary utricles and medullary siphons. 39. Extensive fusion of siphons in pairs (1s). 40. Extensive nodal fusion of three medullary siphons (ls). 41. Halimeda tuna. Detail of primary, secondary and tertiary segments and medullary siphons (ds). 
Natal: Richards Bay, W.G. Rump, 1929 (BM); Port Elizabeth, G.F. Papenfuss, 1955 (BM).

This species, so far known only from the IndoPacific, was recently found in Brazil (E. BandeiraPedrosa et al., unpublished data). In Brazil this species is common on reef flats from Rio Grande do Norte through Espírito Santo states (figure 42) from the intertidal to $26 \mathrm{~m}$ depth. More developed specimens were found at the exposed edges of the reef formation. Segment morphology is rather variable on the reef plateau, and may make its recognition in the field difficult, especially from Halimeda discoidea. This species has also being locally confused with $H$. tuna. Segments with typical morphology are found in more protected areas and in pools. Fertile specimens were found only in the state of Espírito Santo, in July.

Halimeda discoidea Decaisne, Ann. Bot. 18:96. 1842. Type locality: "Kamtschatka" [true provenance unknown].

Figures 6, 7, 18, 35-37.

Thallus erect, single, lightly to moderately calcified; color light-green to green yellowish becoming whitish on drying; up to $11 \mathrm{~cm}$ long; branching sparse to dense, di-trichotomous; holdfast single and small; segments discoid to reniform, with a smooth surface, about $46 \mathrm{~mm}$ wide and $25 \mathrm{~mm}$ long (figures 6, 7). Cortex with 2-3 layers of utricles 65 (74-92) $\mu \mathrm{m}$ long in cross-section (figure 35) and 57 (37-77) $\mu \mathrm{m}$ in diameter in surface view, often laterally fused in pairs (figure 18), holding together strongly even after decalcification; secondary utricles subglobose, $121(92-210) \mu \mathrm{m}$ wide; nodal medullary siphons interwoven and fused in groups of 2-3 for a short distance (figure 36). Gametophores branched, produced from secondary utricles on the surface or margin of the fertile segments, bearing 5-8 globose to pear-shaped gametangia about $103 \mu \mathrm{m}$ wide and $159 \mu \mathrm{m}$ long (figure 37).

Selected material: BRASIL: CEARÁ: Trairi, Guajiru, 21-XII-1991, N.P. Dantas (PEUFR17865); 0456'S, 35¹9' W, 32 m, 14-V-1998, REVIZEE (PEUFR35083); 01 ${ }^{\circ} 43^{\prime} \mathrm{S}, 37^{\circ} 07^{\prime} \mathrm{W}, 54 \mathrm{~m}, 6-\mathrm{VI}-1998$, REVIZEE (PEUFR35086); 0350'S, 37³7' W, 166 m, 12-X-1995, REVIZEE (PEUFR35092). Rio Grande do Norte: 05 17'00"'S, 3508'00"'W, 34 m, 22-I-1980, F.R. Lima (PEUFR4979). PaRAÍBA: $07^{\circ} 15^{\prime} 05^{\prime} \mathrm{S}, 34^{\circ} 36^{\prime} 00^{\prime} \mathrm{W}$, 28 m, 2-IV-1981, G.C. Teixeira (PEUFR5700); 07º $18^{\prime}$ 'S, 34³1'W, 35 m, 22-I-1981, A.I. Kanagawa (JPB10247). Pernambuco: 07²6' S, 34³0’ W, 42 m, 12-V-1998, REVIZEE (PEUFR35081); Fernando de
Noronha, Baía de Sueste, 7-III-1993, S.M.B. Pereira (PEUFR21630); Fernando de Noronha, Baía de Sueste, 2-XI-1985. E.C. Oliveira \& V. Eston (SPF51496). SERGIPE: V-1999, PETROBRAS/UFSE (PEUFR 35097); VIII-1999, PETROBRAS/UFSE (PEUFR35098). BAHIA: Sta Cruz de Cabrália, Coroa Alta, 3-I-1979, E.C. Oliveira (SPF51158); Salvador, Itapoã, 29-VI-2000, M.E. Bandeira-Pedrosa \& M.C. Accioly (PEUFR 35080). EsPírito S ANTO: $17^{\circ} 04^{\prime} \mathrm{S}$, 36 $53^{\circ} \mathrm{W}$, 250-60 m, 14-XI-1997, REVIZEE (PEUFR35093); 17²47'S, 3552'W, 63 m, 13-XI-1997 REVIZEE (PEUFR35095).

Additional material studied: BRASIL: BAHIA: Barra Grande, H.M.S. Challenger Exp., H.N. Moseley, 1876 (BM).

General morphology present some variation on populations of different depth; intertidal specimens tend to be more calcified and densely branched, with smaller and thicker segments. This species was found from Ceará state through Espírito Santo State (figure 42) from the intertidal to $166 \mathrm{~m}$ depth. It was found in the State of Sergipe for the first time. Coloration is darker on specimens from the intertidal than from the subtidal specimens. This species often occurs together with H. opuntia. Fertile material was found only once, in November, 1997, in deep water.

Halimeda gracilis Harvey ex J. Agardh, Acta Universitets Lund 23:82. 1887.

Type locality: Sri Lanka.

Figures 8, 19, 38-40.

Thallus prostrate, moderate to strongly calcified; color whitish, becoming grayish on drying; up to $24 \mathrm{~cm}$ long; branching di-trichotomous; attachment by multiple holdfasts; segments subcylindrical, cuneate to reniform, with a smooth and shiny surface, margin undulate, about $18 \mathrm{~mm}$ wide and $11 \mathrm{~mm}$ long (figure 8 ); segments friable before decalcification, with utricles lightly coalescent after decalcification; cortex with two, rarely three layers of utricles, rounded in outline, 52 (44-67) $\mu \mathrm{m}$ in diameter in surface view (figure 19), and 72 (67-92) $\mu \mathrm{m}$ long in cross section. Every secondary utricle supports up to 8 primary ones; secondary utricles clavate (figure 38 ), 74 (56-92) $\mu \mathrm{m}$ wide and 170 (166-333) $\mu \mathrm{m}$ long. Medullary siphons interwoven, with extensive paired nodal fusions, eventually with three filaments fused together (figures 39, 40).

Selected material: BRASIL: CEARÁ: $01^{\circ} 43^{\prime} \mathrm{S}$, 3707'W, 54 m, 6-VI-1998, REVIZEE (PEUFR35112); 0350'S, 37³7'W, 166 m, 12-X-1995, REVIZEE (PEUFR 


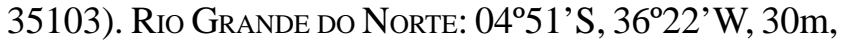
27-III-1980, G.C. Teixeira (PEUFR4500); 05² $17^{\prime} \mathrm{S}$, 3508'W, 34 m, 25-XI-1979, F.R. Lima (PEUFR4975). Paraíba: João Pessoa, Tambaú, 26-IX-1980, (JPB10221) A.I. Kanagawa; 07³4'00”'S, 34²4'00”'W, 20 m, 21-I-1981, A. Fernandes (PEUFR6513). Pernambuco: Ipojuca, Serrambí, 12-VII-1987, M.C. Accioly (PEUFR2784), 07 $28^{\circ} \mathrm{S}, 34^{\circ} 32^{\prime} \mathrm{W}, 36 \mathrm{~m}$, 31-I-1997, REVIZEE (PEUFR35108). SERGIPE: V-1999 PETROBRAS/UFSE (PEUFR35115); VIII-1999, PETROBRAS/UFSE (PEUFR35116). BAHIA: 1338'S, 3845'W, 50 m, 19-X-1997, REVIZEE (PEUFR36471); $15^{\circ} 34^{\prime} \mathrm{S}, 38^{\circ} 51^{\prime} \mathrm{W}, 50 \mathrm{~m}, 25-\mathrm{X}-1997$, REVIZEE (PEUFR36498); 1704'S, 3653'W, 250 m, 14-XI-1997, REVIZEE (PEUFR36478). EsPíRITO SANTO: 19²8'S, $38^{\circ} 22^{\prime} \mathrm{W}, 94$ m, 27-II-1996, REVIZEE (PEUFR36474). Rio de JANEIRO: $20^{\circ} 35^{\prime} \mathrm{S}, 40^{\circ} 05^{\prime} \mathrm{W}, 50 \mathrm{~m}, 24-\mathrm{II}-1982$, Orion (SPF29386); 20³8'S, 4001'W, 57 m, 27-II-1996, REVIZEE (PEUFR36472).

Additional material studied: SRI LANKA: W.H. Harvey 72 (Isotype and photo at $\mathrm{BM}$ )

This species was found from Ceará through Rio de Janeiro states (figure 42), from the intertidal to $250 \mathrm{~m}$ depth. Its occurrence at $250 \mathrm{~m}$ is not enough evidence that it was actually growing at that depth. It is here reported for the states of Sergipe and Bahia for the first time. Specimens from deep water have larger segments that resemble Halimeda tuna, whereas intertidal ones are closer to $H$. opuntia. This probably explain the difficulties many authors had in identifying this species, as can be seen in many herbaria.

Halimeda tuna (Ellis \& Solander) Lamouroux, Nouv. Bull. Sci. Soc. Philom 3:186. 1812. 三 Corallina tuna Ellis \& Solander, Natur. Hist. Zooph. p.111, pl.20, fig.e. 1786.

Type locality: Mediterranean Sea

Figures 9, 10, 23, 41.

Thallus erect, single, moderate to lightly calcified; color light to dark-green, up to $10 \mathrm{~cm}$ long; branching sparse to dense, di-trichotomous; holdfast single and small; basal segments strongly calcified, subcuneate to subcylindrical, remaining segments discoid to subcuneate, with a rough surface, up to $20 \mathrm{~mm}$ wide and $12 \mathrm{~mm}$ long (figures 9, 10). Cortex with usually three, but up to four layers of utricles (figure 41); external utricles keep lightly coalescent after decalcification; polygonal in outline in surface view, with cell walls thicker than the other species (figure 23); 44 (29-55) $\mu \mathrm{m}$ in diameter, in surface view, and 108 (59-196) $\mu \mathrm{m}$ long in cross section; every secondary utricle supports 6 or more primary ones; secondary utricles 48 (44-52) $\mu \mathrm{m}$ wide and 111 (85-177) $\mu \mathrm{m}$ long. Medullary siphons interwoven, with extensive or short nodal fusions in groups of 2-3 as in $H$. cuneata and $H$. discoidea (figures 32, 36).

Selected material: BRASIL: Maranhão: Parcel Manoel Luís, at $10 \mathrm{~m}, 29-\mathrm{V}-2000$, A.C.L.L. Castro \& M.M. Ferreira-Correia (PEUFR38008); 01ํ36'S, $38^{\circ} 10^{\prime} \mathrm{W}, 51 \mathrm{~m}, 18-\mathrm{IX}-1995$, REVIZEE (PEUFR35039). CEArá: Guajiru, Trairi, 21-XII-1991, N.P .Dantas (PEUFR17868). Rio Grande do NoRTE: 04 50'00'S, 35041'00"W, 30 m, 2-III-1980, S.M.B. Pereira \& G.C. Teixeira (PEUFR4451). Paraíba: Ponta do Seixas, 18-XII-1980, F.A.F. Carvalho (JPB10220). Pernambuco: Ipojuca, Serrambi, 15-X-1986, M.C. Accioly \& S.M.B. Pereira (PEUFR12785); Campas, Tamandaré, 16-III-1991, J.A.P. Angeiras (PEUFR20568); Itamaracá, Jaguaribe, 15-X-1997, M.E. Bandeira-Pedrosa \& M.F. Oliveira-Carvalho (PEUFR30523); Tamandaré, 5-V-2000, M.E. BandeiraPedrosa (PEUFR35037). Alagons: Ponta Verde, 4-II-1965, E.C. Oliveira (SPF635); Garça Torta, 27-IV-1998, M.E. Bandeira-Pedrosa \& E.A.C. Guedes (PEUFR30528). BAHIA: Coroa Vermelha, 19-IV-1988, C. Nassar (RFA4363). RIO DE JANEIRO: $18^{\circ} 01^{\prime}$ S, 35 $35^{\circ}$ 'W, $60 \mathrm{~m}, 13-\mathrm{XI}-1997$, REVIZEE (PEUFR36481).

Adittional material studied: FRANCE: Cape Ferrat, Mediterranean, VI-2000, E.C. Oliveira. (PEUFR38016).

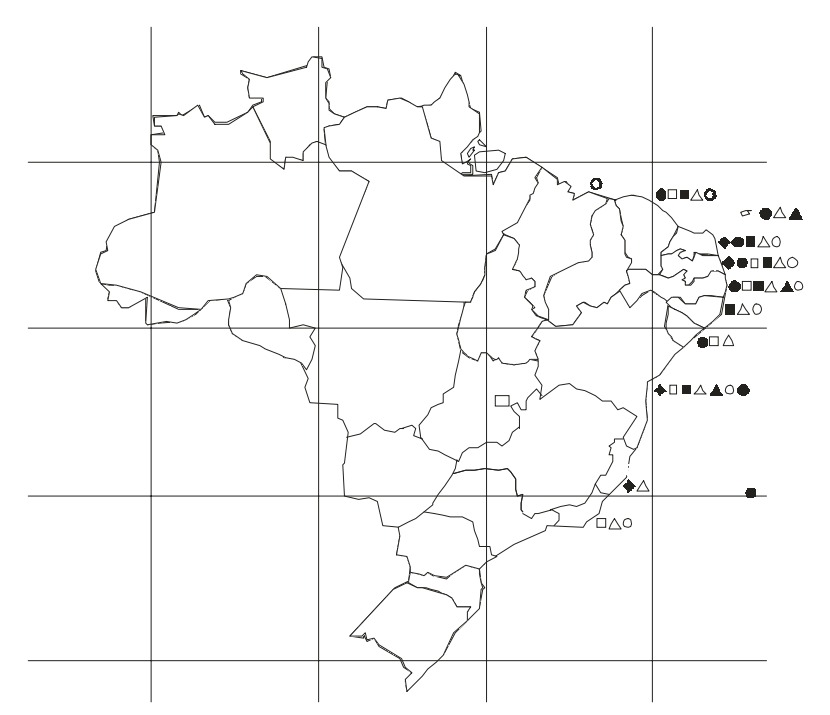

Figure 42. Geographic distribution of Halimeda species on the Brazillian coast: $\bullet=$ Halimeda cuneata,$\bullet=H$. discoidea, $\square=H$. gracilis, $\mathbf{\square}=H$. incrassata, $\triangle=H$. opuntia, $\mathbf{\Delta}=H$. simulans, $\bigcirc=H$. tuna . 
This species was found from the state of Maranhão through the State Rio of Janeiro (figure 42) from the intertidal to $60 \mathrm{~m}$ depth. Intertidal populations are more calcified and with a smaller holdfast, with thicker, smaller and rougher segments, usually darkgreen to brownish.

Key for the identification of Halimeda species reported from Brazil

1. With a bulbous holdfast; nodal medullary siphons fused in a single group (section Rhipsalis)

2. Basal segments usually cylindrical, but also subcuneate or flabellate; primary utricles measuring over $50 \mu \mathrm{m}$ in diameter ......................................................................................... H. incrassata in diameter

H. simulans

1. With one or several non-bulbous holdfasts; nodal medullary siphons fused in groups of 2-3.

3. Attachment by several holdfasts; nodal medullary siphons fused in pairs for a short extension (not more than $100 \mu \mathrm{m}$ ) (section Opuntia)

H. opuntia

3. Attachment by single or multiple holdfasts; nodal medullary siphons fused in groups of 2-3 for more than $100 \mu \mathrm{m}$ (section Halimeda)

4. Thallus flaccid and prostrate, attached by multiple holfasts; secondary utricles clavate H. gracilis

4. Thallus erect with a single conspicuous holdfast; secondary utricles not clavate

5. Segments discoid; secondary utricles inflated, sub-globular

H. discoidea

5. Segments sub-cylindrical, cuneate to reniform; secondary utricles not inflated

6. Basal segments cylindrical, stipe-like; nodal region pedunculate or cushion-like

6. Basal segments subcuneate; nodal region sessile.

H. cuneata H. tuna

\section{Discussion}

One of the problems in identifying species of Halimeda is that gross morphology varies among populations of the same species growing in different habitats, making this criterium unreliable as was already remarked by Barton (1901) and by subsequent authors (e.g. Hillis 1959, Stark et al. 1969, Hillis-Colinvaux 1980). This was fully suported by our observations based on a large sample of specimens from a broad range of depths. This plasticity is certainly the explanation for the confusions we found in local literature (e.g. Pereira 1974, Dantas 1994) and in herbaria. Identification at species level is possible only by a combination of several criteria including habitat, gross morphology and anatomy of mature segments and nodes. Particularly useful are the patterns of nodal medullary siphons fusion, in addition to the size, shape and distribution of the utricles as remarked long ago (Barton 1901). Nodal structure seems to vary less and, therefore, is more useful at the section level. Gametangia arrangement may also help (Kamura 1966, Hillis-Colinvaux 1980) as we have seen in $H$. discoidea and H. cuneata, but they are quite rare and undescribed for some taxa (Hillis-Colinvaux 1980). The utilization of the shape and size of the utricula in surface view under SEM proved to be rewarding allowing species discrimination in some cases if associated with other characters (figures 17-23).

A good example of morphological variability is given by Halimeda opuntia, which is well known for its large variation in branching pattern and segment morphology. This species can form extensive mats with entangled branches as well as loose tufts with distichous branching, in which case it can be easily confused with $\mathrm{H}$. gracilis. Its segments may be flat, subcylindrical, contorted, auriculate, trilobate and crenulate depending on where it is growing. Because of this variability Barton (1901) proposed to divide this taxon into four forms: f. cordata, f. elongata, f. opuntia and f. triloba. Taylor (1960) accepted f. cordata and f. triloba and added f. minor Vickers; however, this division is not supported by our observations for we observed a morphological continuous in large samples and even some specimens with mixed characters.

Halimeda cuneata, $H$. discoidea, $H$. gracilis, and H. tuna, all from section Halimeda Hillis-Colinvaux (1980), are very similar and put together under the H. tuna complex (Hillis 1959). Halimeda cuneata differs from the others by the presence of a distinctive interconnection node between segments formed by torulous, thick-walled filaments (Hillis 1959, HillisColinvaux 1980). It is possible that some of the 
difficulties to species identification may be related to hybridization. However, this is based only on morphology and have no experimental support. This hypothesis has already been suggested by Behar (1972) commenting on the difficulties in distinguishing some specimens of Halimeda cuneata from $H$. discoidea. Within this closely related group, $H$. discoidea can be distinguished microscopically by the presence of inflated or subglobose secondary utricles. However, in H. discoidea the typical form is attributed to intertidal specimens, whereas the deep-water specimens have been described as H. discoidea var. platyloba (Taylor 1960). The same applies for $H$. tuna, where the deep-water specimens have been described as $H$. tuna var. platydisca or $\mathrm{f}$. platydisca (Taylor 1960).

Identification of specimens from deep water is much more complicated because of morphological plasticity (cf. Stark et al. 1969). For example, deep water plants of $H$. gracilis exhibited larger, reniform to subcuneate segments, easily mistaken for the deep-water form of $H$. tuna. This deep-water form of $H$. gracilis was described as H. gracilis f. lata by Taylor (1950).

The recent introduction of gene sequencing as a tool in the classification of Halimeda brings a new set of information (Hillis et al. 1998, Kooistra et al. 2002). This in great part supports the classification based on morphological characters, but not always. For instance in the sectional division of Hillis-Colinvaux (1980) $H$. gracilis appear within the section Halimeda (lineage 3 of , Kooistra et al. 2002) but in this last work it appears in linneage 4. Molecular data of Kooistra et al. (2002) showed that $H$. tuna from the Atlantic and from the Mediterranean were not nearest neighbor. That paper also casts doubts on the supposed pantropical distribution of several species and suggests allopatric speciation through vicariance in the tropical Atlantic and IndoPacific.

On what concerns the distribution of Halimeda in Brazil the seven reported species are concentrated on the northeast coast (figure 42). It is worth noting that all species are present on the coast of Bahia state (figure 42). This fits well with the distribution of reefs in Brazil, the largest concentration being in the state of Bahia as well. The southern limit of the genus is in the Cabo Frio region, Rio de Janeiro State (Zeller 1876, Taylor 1930, 1931, Oliveira Filho 1977), just a little north of a well known area of upwelling.

However, it is on the coast of Pernambuco that the largest biomass of Halimeda spp. seems to be concentrated, especially due to the thick mats of H. opuntia. In this region, dead segments of Halimeda form extensive deposits that have been sporadically utilized commercially (Kempf 1970, 1980, Pereira 1974, Oliveira Filho 1981).

As to vertical distribution the genus is well known for having species that go deep in the sublittoral (e.g. Littler \& Littler 2000, Stark et al. 1969). In Brazil, Halimeda gracilis and $H$. discoidea were found at depths of over $160 \mathrm{~m}$, whereas H. tuna, H. incrassata, $H$. simulans and $H$. opuntia were found up to $60 \mathrm{~m}$. We have a sample of $H$. discoidea dredged from $260 \mathrm{~m}$; however, there is no guaranty that this species was actually growing at that depth.

In conclusion although we have cleared up some confusions on the identification of the Halimeda species in Brazilian herbaria and extended the distribution of several taxa along the coast, we realised that due to morphological convergence in response to habitat and herbivore pressure, the next step would be to check our morphological hypothesis with molecular biology techniques.

Acknowledgements - Dr. Zenilda Bouzon for help with SEM observations and Dr. Ana Malinska for the utilization of the Scanning Electron Microscope facilities at the Universidade Federal de Santa Catarina. Professor Michael J. Wynne corrected the English text and made valuable suggestions to improve the manuscript.

\section{References}

BEHAR, L. 1972. Clorofíceas do litoral Sul do Estado do Espírito Santo. I. Siphonocladales e Siphonales. Dissertação de mestrado, Universidade de São Paulo, São Paulo.

BARTON, E.S. 1901. The genus Halimeda. Siboga-Expeditie Monographe, Leiden 60:1-32.

BOROWITZKA, M.A. \& LARKUM, A.D.W. 1977. Calcification in the green alga Halimeda.V. An ultrastructure study of the thallus development. Journal of Phycology 13:6-16.

DANTAS, N.P. 1994. Estudos taxonômicos dos representantes da ordem Caulerpales (Chlorophyta) da Praia de Guagirú (Estado do Ceará - Brasil). Dissertação de mestrado, Universidade Federal de Pernambuco, Recife.

GILMARTIN, M. 1960. The ecological distribution of the deep water algae of Eniwetok. Ecology 41:210-221.

HILLIS, L.W. 1959. A revision of genus Halimeda (order Siphonales). Publications of the Institute of Marine Sciences 6:321-403.

HILLIS-COLINVAUX, L. 1980. Ecology and taxonomy of Halimeda: primary producer of coral reefs. Advances in Marine Biology 17:1-327. 
HILLIS, L.W., ENGMAN, J.A. \& KOISTRA, W.H.C.F. 1998. Morphological and molecular phylogenies of Halimeda (Chlorophyta, Bryopsidales) identify three evolutionary lineages. Journal of Phycology 34:669-681.

HORTA, P. \& OLIVEIRA, E.C. 2002. Algas marinhas bênticas do Brasil http://www.ib.usp.br/algamare-br (acesso em 10/10/2003).

KAMURA, S. 1966. On the sexual reproduction of two species of Halimeda (Chlorophyta). Bulletin of Arts and Sciences of the University of Ryukyus, Mathematical and Natural Sciences 9:302-313.

KEMPF, M. 1970. Nota preliminar sobre os fundos costeiros da região de Itamaracá (norte do Estado de PernambucoBrasil). Trabalhos Oceanográficos da Universidade Federal de Pernambuco 9-11:95-110.

KEMPF, M. 1980. Perspectiva de exploração econômica dos fundos de algas calcárias da plataforma continental do nordeste do Brasil. Trabalhos Oceanográficos da Universidade Federal de Pernambuco 15:139-164.

KOOISTRA, W.H.C.F., COPPEJANS, E.G.G. \& PAYRI, C. 2002. Molecular systematics, historical ecology, and phylogeography of Halimeda (Bryopsidales). Molecular Phylogenetics and Evolution 24:121-13.

LITTLER, D.S. \& LITTLER, M.M. 2000. Caribbean reef plants. OffShore Graphics Inc., Washington.

OLIVEIRA FILHO, E.C. 1977. Algas marinhas bentônicas do Brasil. Tese de livre docência, Universidade de São Paulo, São Paulo.

OLIVEIRA FILHO, E.C. 1981. Marine phycology and exploitation of seaweeds in South America. In Proceedings of the International Seaweed Symposium (T. Levring, ed.). W. de Gruyter, Berlin v.10, p.97-112.
PEREIRA, S.M.B. 1974. Cloroficeas da Ilha de Itamaracá e arredores (Estado de Pernambuco-Brasil). Dissertação de mestrado, Universidade de São Paulo, São Paulo.

STARK, L.M., ALMODOVAR, L. \& KRAUS, R.W. 1969. Factors affecting the rate of calcification in Halimeda opuntia (L.) Lamouroux and Halimeda discoidea Decaisne. Journal of Phycology 4:305-312.

TAYLOR, W.R. 1930. Algae collected on the "Hassler", "Albatross" and Schmitt Expeditions: I. Marine algae from Brazil. American Journal of Botany 16:621-630.

TAYLOR, W.R. 1931. A synopsis of the marine algae of Brazil. Revue Algologique 5:279-313.

TAYLOR, W.R. 1950. Plantas of Bikini and other northern Marshall Islands. University of Michigan Press, Ann Arbor.

TAYLOR, W.R. 1960. Marine algae of the eastern tropical and subtropical coasts of the Americas. University of Michigan Press, Ann Arbor.

UGADIM, Y. \& PEREIRA, S.M.B. 1978. Deep-water marine algae from Brazil collected by the Recife Commission. I. Chlorophyta. Ciência e Cultura 30:839-842.

WILLIAMS, L.G. \& BLOMQUIST, H.L. 1947. A collection of marine algae from Brazil. Bulletin of the Torrey Botanical Club 74:383-397.

ZELLER, G. 1876. Algae brasiliensis circa Rio de Janeiro a Dr. Glaziou, Horti publici directore collectae. In Symbolae ad floram Brasiliae centralis cognoscendam, (E. Warming, ed.). Videnskabernes Meddelelser Natur Foren, Københaven, v.22, p.426- 432. 